\title{
Engineering Geology of Sidosari Area, Magelang, Central Java, Indonesia
}

\author{
Diyaning Ratri and I Gde Budi Indrawan* \\ Department of Geological Engineering, Faculty of Engineering, Gadjah Mada University, Yogyakarta, Indonesia
}

\begin{abstract}
Development of settlement area in Sidosari area and the surroundings requires complete understanding of the engineering geological conditions, including susceptibility to landslides, to prevent damaged properties and loss of lives. Surface engineering geological mapping at a 1:25000 scale was conducted to develop a detailed landslide susceptibility map for spatial planning and to identify most controlling factor of landslides in the research area based on conditions of geomorphology, rock and soil, geological structure, groundwater seepage, and land use. The engineering geological mapping showed that landslides commonly occurred in the moderate slopes of the denudational hill landform having slope inclination ranging from 9 to $17^{\circ}$, in the areas covered by residual soils of the vitric tuff 2 unit, in the areas of no groundwater seepage, and in the settlement areas, including in Kranjang Lor area where soil creeping occurred. The high susceptibility zone covered $55.5 \%$ of the research area and was characterized by having slope inclinations ranging from 9 to $35^{\circ}$, engineering geological units of vitric tuff 2 and tuff breccia, and land uses of rice and dry fields and settlement. The low cohesion and very high swelling potential of the residual soils of the vitric tuff 2 unit were considered to be the main controlling factor of landslides in the research area.
\end{abstract}

Keywords: Engineering geological mapping - Landslide susceptibility · Soil creeping · Indonesia.

\section{INTRODUCTION}

Sidosari area and the surroundings are parts of District of Salaman, Regency of Magelang, Province of Central Jawa, Indonesia. Regional Geological Map of Yogyakarta Sheet of a 1:100000 scale produced by Rahardjo et al. (1995) indicates that Sidosari area and the surroundings consist of volcaniclastic deposits of Old Sumbing and Young Sumbing and alluvium deposits covering Tertiary Kebobutak Formation. The volcaniclastic rocks were mostly weathered and had low strength (Novianto et al., 1997). Regional Landslide Hazard Map of a 1:100000 scale produced by Pusat Vulkanologi dan Mitigasi Bencana Geologi (2015) indicates that steep slopes in the

\footnotetext{
${ }^{*}$ Corresponding author: IG.B. INDRAWAN, Department of Geological Engineering, Gadjah Mada University. Jl. Grafika 2 Yogyakarta, Indonesia. E-mail: igbindrawan@ugm.ac.id
}

Sidosari area and the surroundings were prone to landslide.

Population growth in the research area demands increased housing area. The research area has been used for rice and dry fields $(86.7 \%)$ and housing $(13.3 \%)$. Considering the relatively low population density of the research area, development of settlement area in Sidosari area and the surroundings is feasible. However, a number of landslides, including soil creeping, have occurred in Sidosari area and the surroundings and have threatened the local community (Figure 1). Development of settlement area in Sidosari area and the surroundings requires complete understanding of the engineering geological conditions, including susceptibility to soil creeping, to prevent damaged properties and loss of lives.

This paper presents results of engineering geological mapping in Sidosari area and the surroundings at a $1: 25000$ scale that was con- 

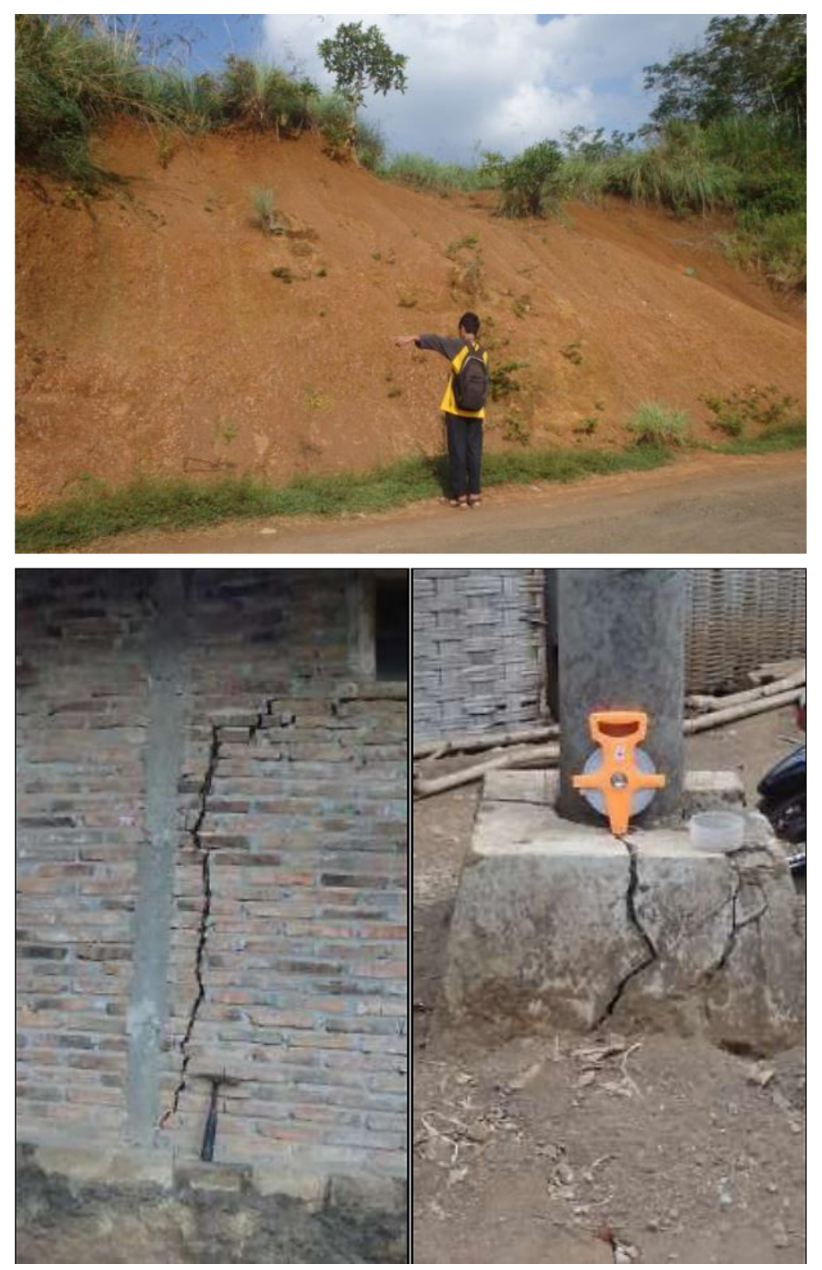

Figure 1: Typical landslides along road cut slopes in the research area and cracks in wall and foundation of houses in Kranjang Lor area induced by soil creeping.

ducted to develop a detailed landslide susceptibility map for spatial planning and to identify most controlling factor of landslides in the research area based on conditions of geomorphology, rock and soil, geological structure, groundwater seepage, and land use. The engineering geological conditions of the research area are presented and the most controlling factor of landslides is highlighted.

\section{Methodology}

Field and laboratory investigations, involving investigations of conditions of geomorphology, rock and soil, geological structure, groundwater seepage, land use, and susceptibility of the research area to landslide, were conducted during surface engineering geological mapping at a 1 : 25000 scale. The mapping scale was selected since it was a minimum requirement for urban spatial planning as specified in the Peraturan Pemerintah Republik Indonesia Nomor 8 Tahun 2013.

Analysis of topographical map, produced by Badan Koordinasi Survey dan Pemetaan Nasional (2001) using a geographical information system (GIS) tool and field observation of surface topography and active geomorphological processes during geomorphical survey were conducted to develop a geomorphological map. The research area was classified into several geomorphological units following terrain classification proposed by Van Zuidam (1983). Slope inclination map was developed following slope classification proposed by Kementerian Energi dan Sumber Daya Mineral (2000). Investigation of rock physical properties and geological structures were conducted and the results were presented in a geological map. Genetic classification of igneous rocks was conducted following IUGS classification proposed by Streckeisen (1978), while that of pyroclastic rocks was performed following classifications proposed by Schmid (1981) and Fisher (1966). In addition to physical properties and genetic classification, investigation of engineering properties and engineering classification of rock and soil were also conducted and the results were presented in an engineering geological map of rocks and soils. Although Dearman (1991) recommended engineering formation to be used as engineering geological unit for medium-scale (1:10000 or greater) map, zonation of engineering geological units in this research was conducted based on lithological type, as per local practice of geological mapping. Weathering degree of rocks was determined by following classification proposed by ISRM (1981). Strength of intact rocks was determined by the point load method and the field indices recommended by ISRM (1981), while strength of rock masses was estimated by Geological Strength Index (GSI) (Marinos et al., 2004). Classification of soils for engineering purposes was performed by adopting procedures specified by ASTM D2487-11. Soil water content, density, and specific gravity were determined by adopting procedures specified by ASTM D2216-10, ASTM D2937-00, ASTM D854-14, respectively. Shear strength of soils was determined by direct shear test following ASTM D3080-98. Swelling potential 
of the soils was determined by plotting liquid limit (LL) and plasticity index (PI) values in the swelling potential chart proposed by Dakshanamurty et al. (1973). As groundwater was considered as one of controlling factors in landslides, field observation of groundwater seepage on the slopes was conducted, upon which a map of groundwater seepage intensity was developed. The map of groundwater seepage intensity contained classification of groundwater seepage intensity as proposed by Kementrian Pekerjaan Umum (2007). Field observation and interpretations of RBI and satellite image of the existing land uses were conducted to develop a land-use map.

Data of slope inclination, rock and soil, groundwater seepage, and land use were used as parameters in the zonation of landslide susceptibility. Each of the parameters was given a weight based on Analytical Hierarchy Process (AHP) (Saaty, 1990). Criteria for landslide susceptibility zonation are shown in Table 1 and Table 2. The engineering geological unit, slope inclination, land use, and groundwater seepage intensity were given $52.6 \%, 30.1 \%, 11 \%$, and $6.3 \%$ weights, respectively. Each classification or sub parameter of a parameter was assigned a value from 1 to 3 , where the highest value indicated the most susceptible parameter to cause a landslide, and a score of each classification was obtained by multiplying the value by the weight. The research area was then divided into three zones of low, moderate, and high landslide susceptibilities.

Table 1: Pairwise comparison matrix in the zonation of landslide susceptibility.

\begin{tabular}{lcccc}
\hline \multicolumn{1}{c}{ Parameter } & $\begin{array}{c}\text { Rock } \\
\text { and } \\
\text { soil }\end{array}$ & $\begin{array}{c}\text { Slope } \\
\text { incli- } \\
\text { nation }\end{array}$ & $\begin{array}{c}\text { Land } \\
\text { use }\end{array}$ & $\begin{array}{c}\text { Ground- } \\
\text { water } \\
\text { seepage }\end{array}$ \\
\hline $\begin{array}{l}\text { Rock and soil } \\
\text { Slope }\end{array}$ & 1 & 2 & 5 & 7 \\
$\begin{array}{l}\text { inclination } \\
\text { Land use }\end{array}$ & $1 / 2$ & 1 & 3 & 5 \\
$\begin{array}{l}\text { Groundwater } \\
\text { seepage }\end{array}$ & $1 / 5$ & $1 / 3$ & 1 & 2 \\
\hline
\end{tabular}

Table 2: Criteria for zonation of landslide susceptibility.

\begin{tabular}{|c|c|c|c|}
\hline Parameter & Classification & Value & Weight \\
\hline \multirow[t]{3}{*}{ Rock and soil } & $\begin{array}{l}\text { Vitric tuff } 2 \text { and } \\
\text { tuff breccia }\end{array}$ & 3 & \multirow[t]{3}{*}{$52.6 \%$} \\
\hline & $\begin{array}{l}\text { Andesite } \\
\text { breccia }\end{array}$ & 2 & \\
\hline & $\begin{array}{l}\text { Vitric tuff } 1 \text { and } \\
\text { sand-boulder }\end{array}$ & 1 & \\
\hline \multirow{3}{*}{ Slope inclination } & $>17$ & 3 & \multirow{3}{*}{$30.1 \%$} \\
\hline & $9-17$ & 2 & \\
\hline & $<9$ & 1 & \\
\hline \multirow{3}{*}{ Land use } & Settlement & 3 & \multirow{3}{*}{$11 \%$} \\
\hline & $\begin{array}{l}\text { Rice and dry } \\
\text { fields }\end{array}$ & 2 & \\
\hline & Forest & 1 & \\
\hline \multirow{3}{*}{$\begin{array}{l}\text { Groundwater } \\
\text { seepage intensity }\end{array}$} & High intensity & 3 & \multirow{3}{*}{$6.3 \%$} \\
\hline & Low intensity & 2 & \\
\hline & None & 1 & \\
\hline
\end{tabular}

\section{RESUltS AND DisCUSSION}

Geomorphological map of the research area is shown in Figure 2, while the slope inclination map is shown in Figure 3. The research area consisted of geomorphological units of fluvial origin, which consisted of alluvial plain and fluvial channel landforms, and denudational origin, which consists of denudational hill landforms of moderate and steep slopes. The alluvial plain and fluvial channel landforms had slope inclination ranging from 0 to $9^{\circ}$, while the denudational hill landforms of moderate and steep slopes had slope inclination ranging from 9 to $17^{\circ}$ and from 17 to $>35^{\circ}$, respectively (Figure 3). Surface geological processes that were active in the denudational hill landforms were mainly erosion, while those in the alluvial plain and fluvial channel landforms were erosion and deposition.

During the field observation, 37 landslides were identified. Most of the landslides were relatively small having approximately size of $3 \mathrm{~m}$ wide by $3 \mathrm{~m}$ high, although slightly larger landslides having approximately size of $4 \mathrm{~m}$ wide by $7 \mathrm{~m}$ high were also observed. Landslides commonly occurred in the moderate slopes of the denudational hill landform, including in Kranjang Lor area where the soil creeping occurred. Although the alluvial plain landform had al- 


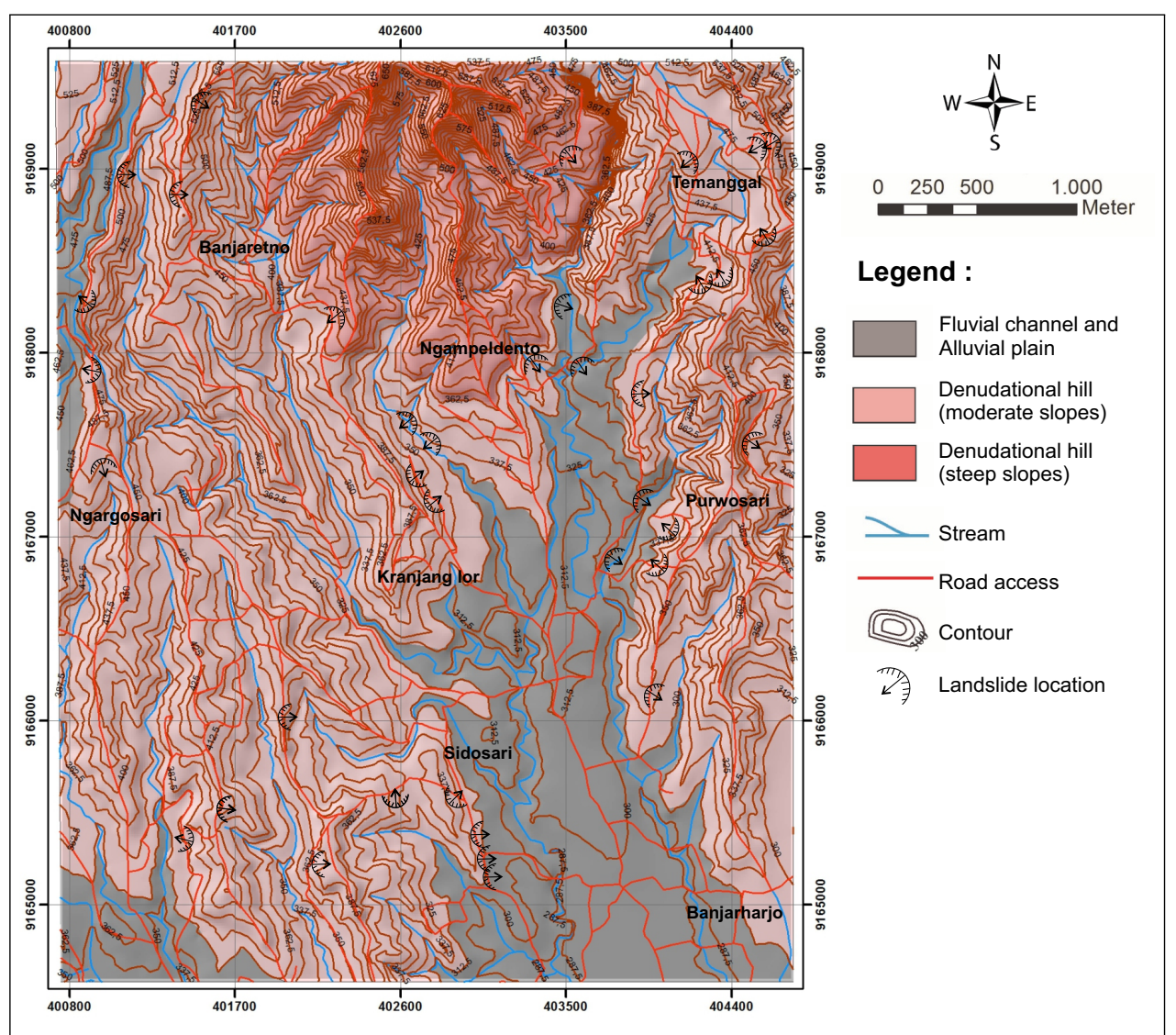

Figure 2: Geomorphological map.

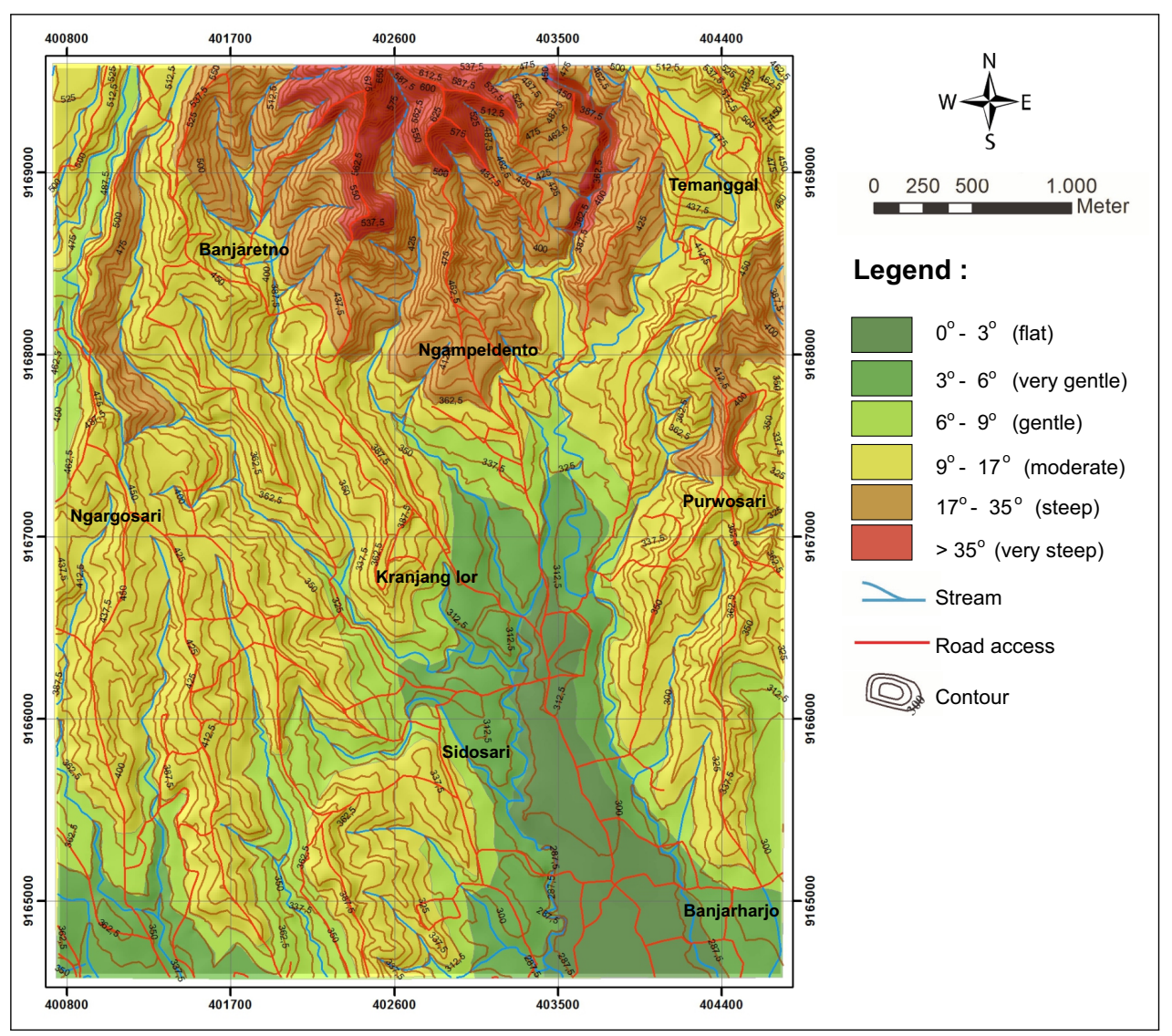

Figure 3: Slope inclination map. 
most flat to gentle slopes, a number of landslides along road cut slopes also occurred. The limited number of landslides in the steep slopes of the denudational hill landform as compared to those in the areas having gentler slopes indicates slope inclination was not the main controlling factor of landslides in the research area.

Geological map of the research area is shown in Figure 4. The research area consists of geological units of andesite breccia of Old Sumbing Volcano deposit, vitric tuff 1 of Young Sumbing Volcano deposit, tuff breccia of Young Sumbing Volcano deposit, vitric tuff 2 of Young Sumbing Volcano deposit, and unconsolidated sandboulder deposit. Physical properties of the geological units are described in Table 3. Vitric tuff 1 was essentially coarser than vitric tuff 2 and contained chlorite as a secondary mineral while vitric tuff 2 contained clay as a secondary mineral. Geological structure observed in the research area was tension joints with $\mathrm{N} 171^{\circ} \mathrm{E}$ orientation developed in the andesite breccia unit.

As engineering characteristics of the geological units were considerably different, the research area was also divided into engineering geological units of andesite breccia, vitric tuff 1, tuff breccia, vitric tuff 2, and unconsolidated sand-boulder. Engineering geological units and engineering characteristics of rocks and soils in the research area are shown Figure 5 and Table 3 , respectively. In general, the andesite breccia, vitric tuff 1 , tuff breccia, and vitric tuff 2 units were highly to completely weathered, had relatively low strengths, and were classified as poor quality rock masses. Residual soils of the engineering geological units had thickness ranging from 1 to $1.5 \mathrm{~m}$ and relatively low density and medium to very high swelling potential. Landslides commonly occurred in the areas covered by vitric tuff 2 unit and partly in the areas consisting of the andesite breccia unit. The low cohesion and very high swelling potential of residual soils of the vitric tuff 2 unit were likely responsible for the landslides in the research area, including soil creeping in Kranjang Lor. As pointed out by Wesley (2010), residual soils commonly have good bearing capacity for foundation. Due to the low of cohesion, however, residual soil slopes are prone to landslides.

Field observation of groundwater seepage in- dicated that two zones of groundwater seepage existed in the research area (Figure 6). Groundwater mainly seeped through the joints and partly through contacts between moderately weathered and residual soil of the andesite breccia unit, representing permeable and impermeable layers, respectively, to groundwater flow. While landslides commonly occurred in areas of no groundwater seepage, only a landslide in Krinjing area (i.e., northwest direction from Temanggal area) associated with the existence of groundwater seepage. This implies that groundwater seepage was not the most controlling factor of landslides in the research area.

Rice and dry fields were the main land use in the research area, while settlement area was only a small part of the research area (i.e., about $13.3 \%$ ) (Figure 7). Landslides most commonly occurred in the settlement areas. Live and dead loads induced soil creeping in Kranjang Lor area having moderate slope inclination. Road cut slopes consisting of low strength soils and rocks in the research area were commonly unprotected and, therefore, prone to failure particularly during rainy seasons.

Map of landslide susceptibility is shown in Figure 8 . The high susceptibility zone covered approximately $55.5 \%$ of the research area and was characterized by having slope inclinations ranging from 9 to $35^{\circ}$, engineering geological units of vitric tuff 2 and tuff breccia, and land uses of rice and dry fields and settlement. The moderate susceptibility zone consisted $38.3 \%$ of the research area and was characterized by having slope inclinations ranging from 6 to $>35^{\circ}$, engineering geological units of vitric tuff and tuff breccia units, and all types of land uses in the research area. The low susceptibility zone occupied $6.2 \%$ of the research area and was characterized by having slope inclinations ranging from 0 to $17^{\circ}$, engineering geological units of vitric tuff 1 and sand-boulder, and land uses of rice and dry fields. Plot of landslide distribution (Figure 2) on the landslide susceptibility map (Figure 8 ) showed that $31(84 \%)$ landslides occurred in the high susceptibility zone, $6(16 \%)$ landslides occurred in the moderate susceptibility zone, and none of landslides occurred in the low susceptibility zone. The reasonably agreement between land- 


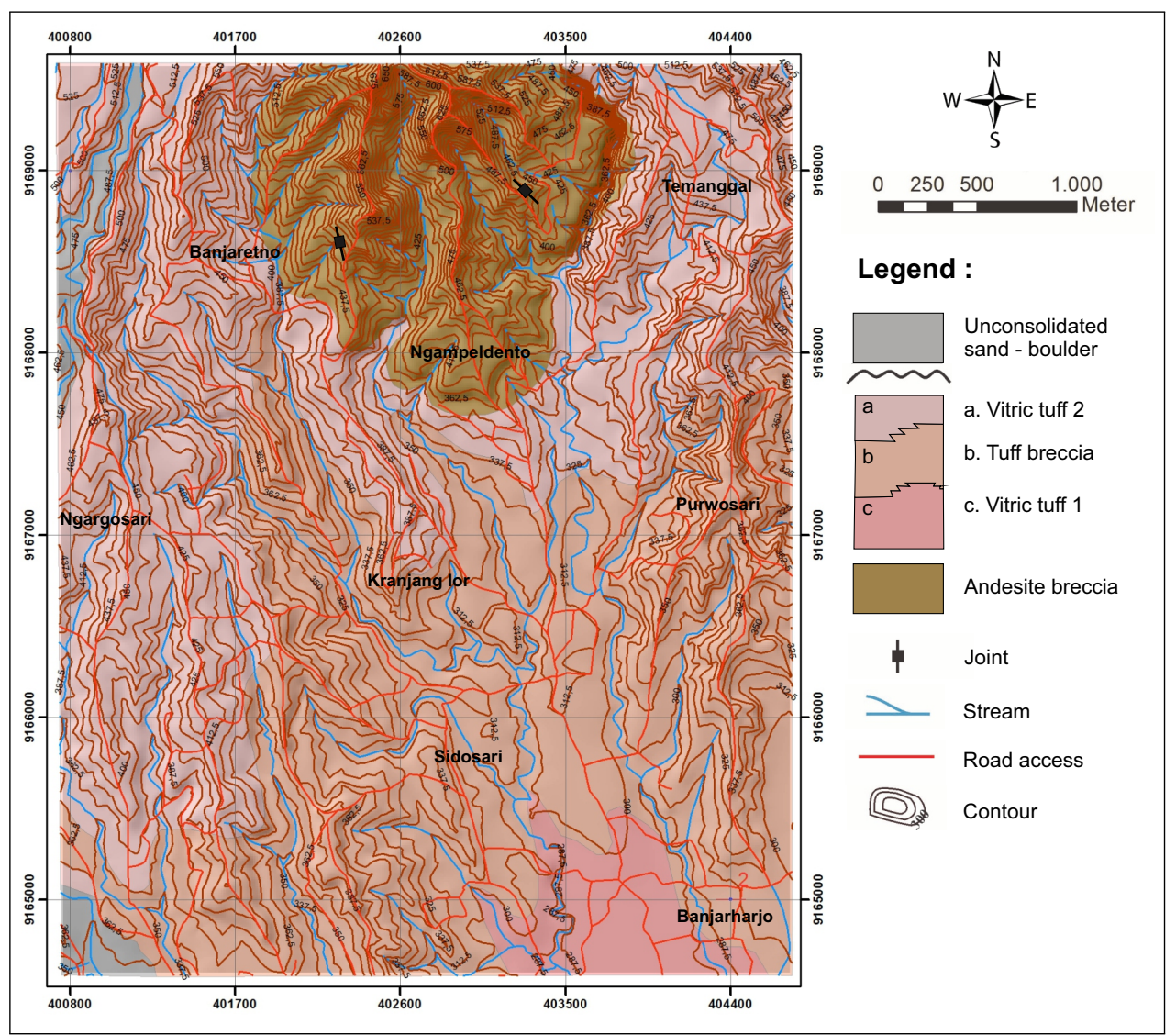

Figure 4: Geological map.

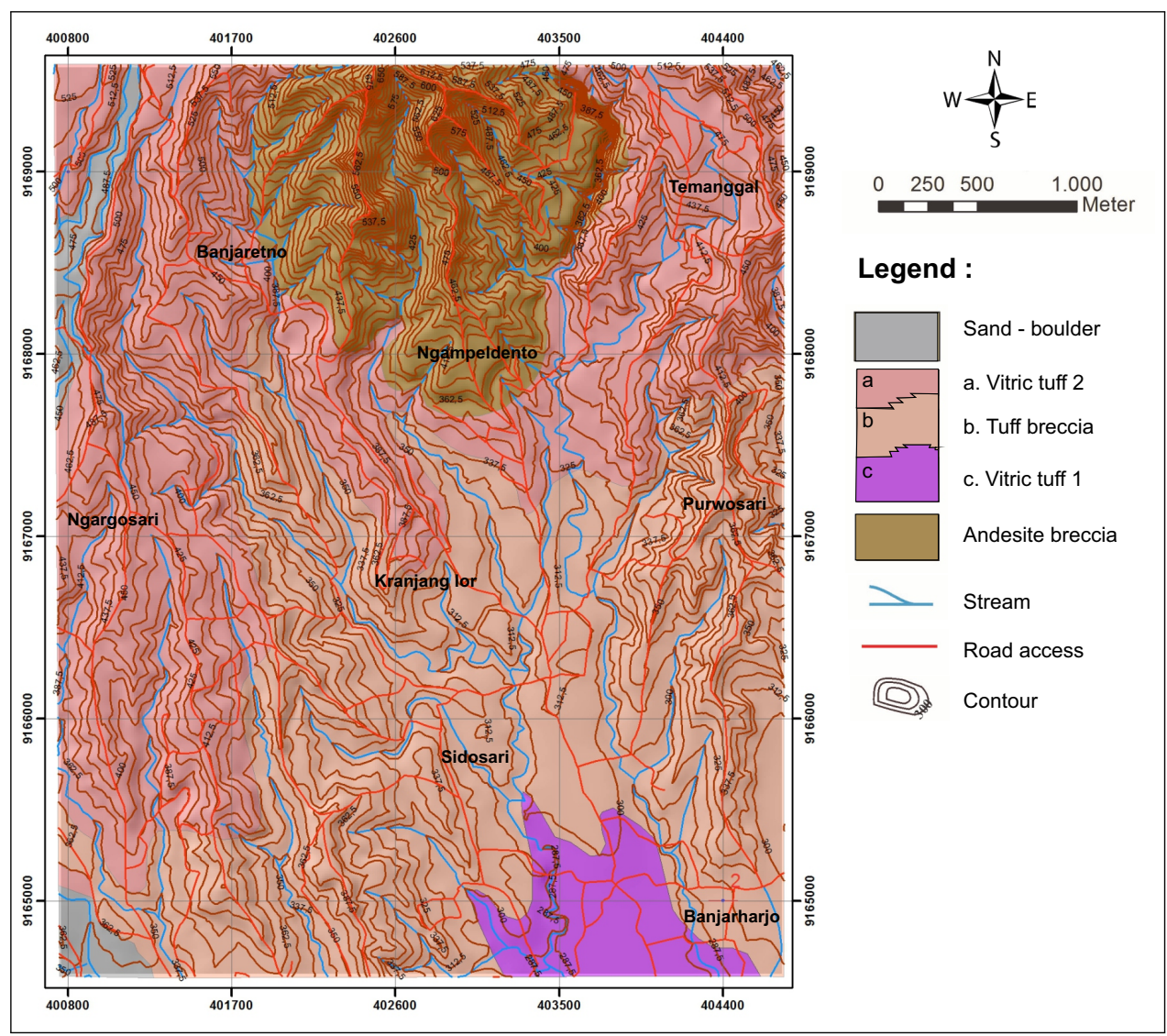

Figure 5: Engineering geological map of rocks and soils. 
Table 3: Engineering characteristics of rocks and soils.

\begin{tabular}{|c|c|c|}
\hline Unit & Description & Engineering characteristics \\
\hline Sand-boulder & $\begin{array}{l}\text { The unit mainly consisted of } \\
\text { unconsolidated sand- and } \\
\text { boulder-size sediments. The } \\
\text { sand-size sediments were brownish } \\
\text { grey and fine sands contained small } \\
\text { fractions of gravels. The } \\
\text { boulder-size sediments were } \\
\text { holocrystalline and grey colored } \\
\text { andesite rocks. }\end{array}$ & $\begin{array}{l}\text { The andesite rocks were fresh and classified as extremely hard rocks (> } 250 \\
\mathrm{MPa} \text { ). }\end{array}$ \\
\hline Vitric tuff 2 & $\begin{array}{l}\text { The unit consisted of brownish } \\
\text { vitric tuff having } 0.3-1 \mathrm{~mm} \text { size of } \\
\text { angular fragment and }<0.3 \mathrm{~mm} \text { size } \\
\text { of cementing material (matrix), } \\
\text { poor sortation, open fabric, and } \\
\text { massive structure. } \\
\text { The residual soil above the unit } \\
\text { became progressively finer toward } \\
\text { the ground surface from reddish } \\
\text { brown sandy silt to yellowish } \\
\text { brown silt. }\end{array}$ & $\begin{array}{l}\text { The unit had weathering degree: moderate to high, intact rock strength: } \\
<1-25 \mathrm{MPa} \text {, and GSI: } 0-30 \text {. } \\
\text { Sandy silt had natural water content }(w): 34.3-43.4 \% \text {, dry density }\left(\rho_{d}\right) \text { : } \\
1.2-1.3 \mathrm{~g} / \mathrm{cm}^{3} \text {, specific gravity }\left(G_{s}\right): 2.63-2.68 \mathrm{~g} / \mathrm{cm}^{3}, \text { void ratio }(e): \\
1.03-1.06 \text {, saturation degree }(S): 87.6-97.8 \% \text {, liquid limit }(L L): 41.9-48.2 \% \text {, } \\
\text { plastic limit }(P L): 30.8-34.7 \% \text {, grain size distribution: } 32.5-49.5 \% \text { coarse and } \\
50.5-67.5 \% \text { fine, USCS: sandy silt }(\mathrm{ML}) \text {, and swelling potential: high. } \\
\text { Silt had natural water content }(w): 37.2-41 \% \text {, dry density }(\mathrm{rd}): 1.1-1.2 \\
\mathrm{~g} / \mathrm{cm}^{3} \text {, specific gravity }\left(G_{s}\right): 2.30-2.34 \mathrm{~g} / \mathrm{cm}^{3} \text {, void ratio }(e): 0.98-1.15 \text {, } \\
\text { saturation degree }(S): 75.5-96.1 \% \text {, liquid limit }(L L): 74.7-75.9 \%, \text { plastic limit } \\
(P L): 46.5-50.6 \% \text {, grain size distribution: } 9.2-9.7 \% \text { coarse and } 90.3-90.8 \% \\
\text { fine, USCS: elastic silt }(\mathrm{MH}) \text {, swelling potential: very high, internal friction } \\
\text { angle }(\phi): 15.5-31.7^{\circ} \text { and cohesion }(\mathrm{c}): 0.1-0.2 \mathrm{~kg} / \mathrm{cm}^{2} .\end{array}$ \\
\hline Tuff breccia & $\begin{array}{l}\text { The unit consisted of brownish grey } \\
\text { tuff breccia having } 4->25 \mathrm{~cm} \\
\text { angular fragment and } 0.5-2 \mathrm{~mm} \\
\text { size of cementing material (matrix), } \\
\text { poor sortation, open fabric, and } \\
\text { massive structure. Residual soil } \\
\text { above the unit was dominated by } \\
\text { dark brown to reddish brown sandy } \\
\text { silt }\end{array}$ & $\begin{array}{l}\text { The unit had weathering degree: high to complete, intact rock strength: }<1-5 \\
\mathrm{MPa} \text {, and GSI: } 0-10 \text {. } \\
\text { Sandy silt had natural water content }(w): 36.8-46 \% \text {, dry density }\left(\rho_{d}\right): 1.2 \\
\mathrm{~g} / \mathrm{cm}^{3} \text {, specific gravity }\left(G_{s}\right): 2.43-2.45 \mathrm{~g} / \mathrm{cm}^{3} \text {, void ratio }(e): 0.98-1.15 \text {, } \\
\text { saturation degree }(S): 91.6-97.9 \% \text {, liquid limit }(L L): 58.5-58.9 \% \text {, plastic limit } \\
(P L): 40.1-43.9 \% \text {, grain size distribution: } 21.1-21.5 \% \text { coarse and } 78.5-79.3 \% \\
\text { fine, USCS: elastic silt with sand }(\mathrm{MH}) \text {, and swelling potential: high. }\end{array}$ \\
\hline Vitric tuff 1 & $\begin{array}{l}\text { The unit consisted of grey vitric tuff } \\
\text { having } 0.3-1 \mathrm{~mm} \text { angular fragment } \\
\text { and }<0.3 \mathrm{~mm} \text { size of cementing } \\
\text { material (matrix), poor sortation, } \\
\text { open fabric, and massive structure. } \\
\text { The residual soil above the unit } \\
\text { changed gradually finer toward the } \\
\text { ground surface from brownish grey } \\
\text { silty sand to brown sandy silt. }\end{array}$ & $\begin{array}{l}\text { The unit had weathering degree: complete, intact rock strength: }<1 \mathrm{MPa} \text {, } \\
\text { and GSI: } 0-5 \text {. } \\
\text { Silty sand had natural water content }(w): 69.9 \% \text {, dry density }\left(\rho_{d}\right): 0.9 \mathrm{~g} / \mathrm{cm}^{3} \text {, } \\
\text { specific gravity }\left(G_{S}\right): 2.51 \mathrm{~g} / \mathrm{cm}^{3} \text {, void ratio }(e): 1.79 \text {, saturation degree }(S): \\
97.9 \% \text {, liquid limit }(L L): 74.6 \% \text {, plastic limit }(P L): 53 \% \text {, grain size } \\
\text { distribution: } 53.1 \% \text { coarse and } 46.9 \% \text { fine, USCS: silty sand }(\mathrm{SM}) \text {, swelling } \\
\text { potential: medium. } \\
\text { Sandy silt had natural water content }(w): 36.2 \% \text {, dry density }\left(\rho_{d}\right): 1 \mathrm{~g} / \mathrm{cm}^{3} \text {, } \\
\text { specific gravity }\left(G_{S}\right): 2.48 \mathrm{~g} / \mathrm{cm}^{3} \text {, void ratio }(e): 1.52, \text { saturation degree }(S) \text { : } \\
59.2 \% \text {, liquid limit }(L L): 74.6 \%, \text { plastic limit }(P L): 36.6 \% \text {, grain size } \\
\text { distribution: } 17.9 \% \text { coarse and } 82.1 \% \text { fine, USCS: silt with sand }(\mathrm{ML}) \text {, and } \\
\text { swelling potential: medium. }\end{array}$ \\
\hline Andesite breccia & $\begin{array}{l}\text { The unit consisted of andesite } \\
\text { breccia having } 4->25 \mathrm{~cm} \text { size of } \\
\text { angular fragment, and } 0.5-2 \mathrm{~mm} \\
\text { size of cementing material (matrix), } \\
\text { poor sortation, open fabric, and } \\
\text { massive structure. } \\
\text { Residual soil above the unit was } \\
\text { dominated by brown silt. }\end{array}$ & $\begin{array}{l}\text { The unit had weathering degree: moderate to high, intact rock strength: } \\
\text { 1-25 MPa, and GSI: } 15-35 . \\
\text { Silt had natural water content }(w): 44.6 \% \text {, dry density }\left(\rho_{d}\right): 0.9 \mathrm{~g} / \mathrm{cm}^{3} \text {, } \\
\text { specific gravity }\left(G_{s}\right): 2,64 \mathrm{~g} / \mathrm{cm}^{3} \text {, void ratio }(e): 1.82 \text {, saturation degree }(S) \text { : } \\
64.9 \% \text {, liquid limit }(L L): 67.2 \% \text {, plastic limit }(P L): 45.2 \% \text {, grain size } \\
\text { distribution: } 13.4 \% \text { coarse and } 86.6 \% \text { fine, USCS: elastic silt }(\mathrm{MH}) \text {, and } \\
\text { swelling potential: high. }\end{array}$ \\
\hline
\end{tabular}




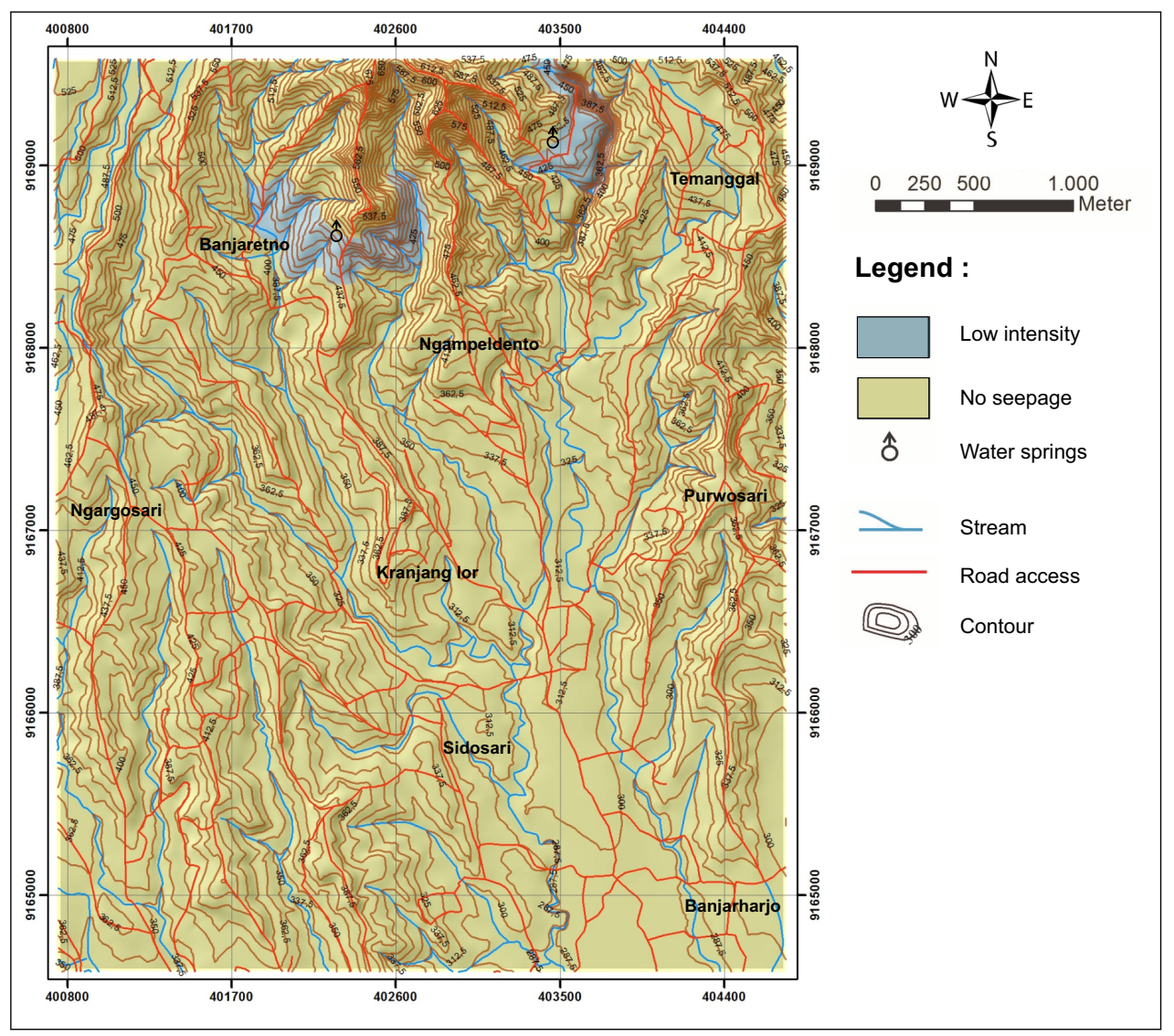

Figure 6: Map of groundwater seepage intensity.

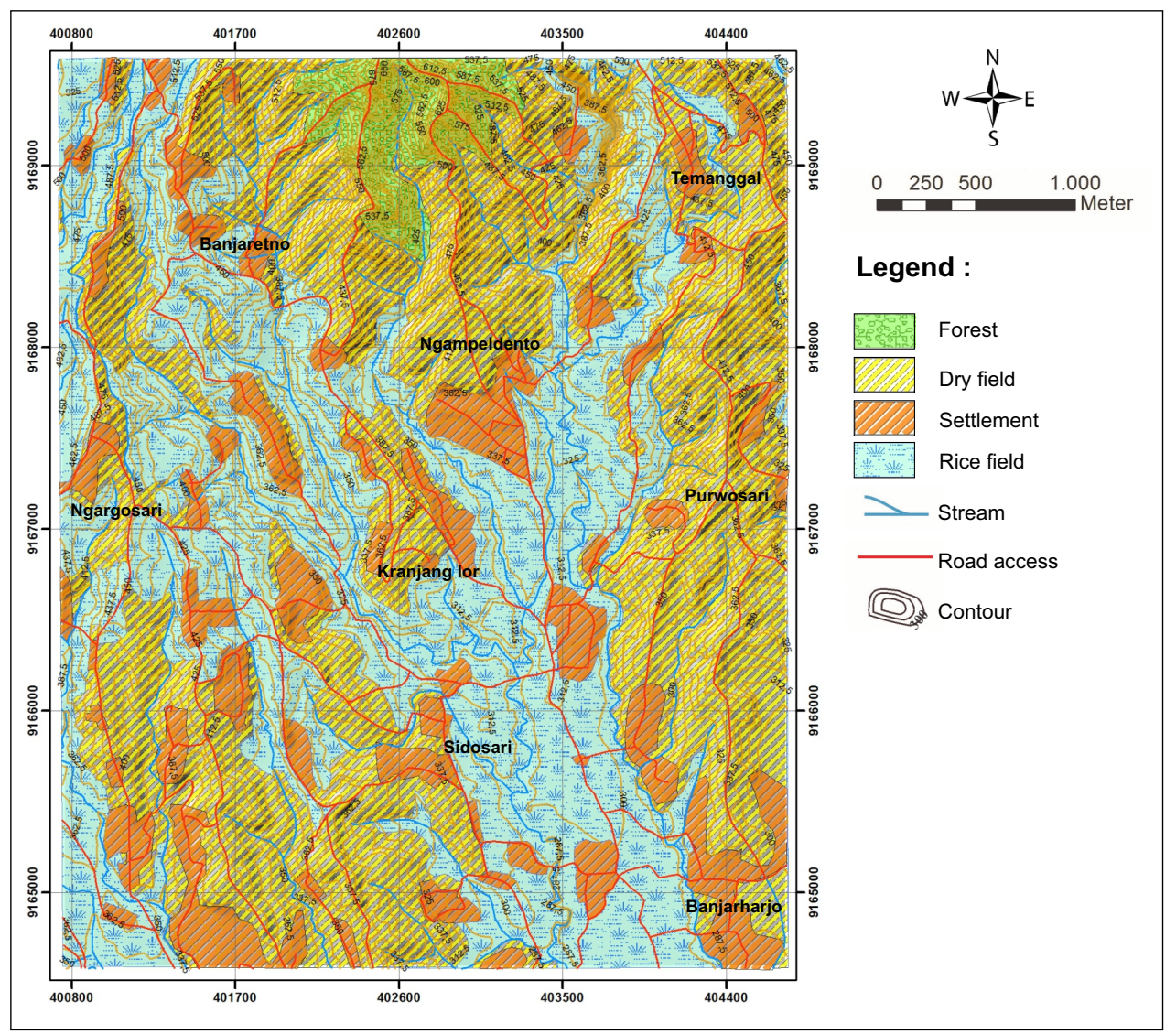

Figure 7: Land-use map. 
slide distribution and the landslide susceptibility level implies that the methodology applied in the landslide susceptibility zonation was acceptable.

For spatial planning, the zones of high susceptibility to landslides should be strictly prohibited for settlement areas. Learning from the case of Kranjang Lor area, due to the relatively low strength of soils and rocks consisting the research area, mass movement may occur in areas having gentle slopes.

\section{Conclusion}

Engineering geological mapping at a 1:25000 scale was conducted to develop a detailed landslide susceptibility map and to identify most controlling factor of landslides in the research area. Landslides, including soil creeping, commonly occurred in the moderate slopes of the denudational hill landform having slope inclination ranging from 9 to $17^{\circ}$, in the areas covered by residual soils of the vitric tuff 2 unit, in the areas of no groundwater seepage, and in the settlement areas, including in Kranjang Lor area where soil creeping occurred. The high susceptibility zone covered $55.5 \%$ of the research area and was characterized by having slope inclinations ranging from 9 to $35^{\circ}$, engineering geological units of vitric tuff 2 and tuff breccia, and land uses of rice and dry fields and settlement. The low cohesion and very high swelling potential of the residual soils of the vitric tuff 2 unit were considered to be the main controlling factor of landslides in the research area.

\section{ACKNOWLEDGEMENTS}

The research was supported by Department of Geological Engineering Universitas Gadjah Mada. The assistance of Ms. Tran Thi Thanh Thuy during the field and laboratory investigations is gratefully acknowledged.

\section{REFERENCES}

ASTM D854-14, Standard Test Methods for Specific Gravity of Soil Solids by Water Pycnometer, ASTM International, West Conshohocken, PA, 2014.

ASTM D2216-10, Standard Test Methods for Laboratory Determination of Water (Moisture) Content of Soil and Rock by Mass, ASTM International, West Conshohocken, PA, 2010.

ASTM D2487-11, Standard Practice for Classification of Soils for Engineering Purposes (Unified
Soil Classification System), ASTM International, West Conshohocken, PA, 2011.

ASTM D2937-00, Standard Test Method for Density of Soil in Place by the Drive-Cylinder Method, ASTM International, West Conshohocken, PA, 2000.

ASTM D3080-98, Standard Test Method for Direct Shear Test of Soils Under Consolidated Drained Conditions, ASTM International, West Conshohocken, PA, 1998.

Badan Koordinasi Survey dan Pemetaan Nasional (2001) Peta Rupa Bumi Digital Indonesia Lembar 1408-234 Mungkid, Bogor, BAKOSURTANAL.

Barker, A.J. (2014) A Key for Identification of Rockforming Minerals in Thin-Section, UK, University of Southampton.

Dakshanamurty, V., Raman, V. (1973) A simple method of identifying an expansive soil, Soils and Foundations: Japanese Society of SMFE, 13. 1, March.

Dearman, W.R. (1991) Engineering Geological Mapping, Oxford, Butterworth-Heinemann Ltd.

Fisher, R.V. (1966) Rocks composed of volcanic fragments and their classification, Amsterdam, Elsevier Publishing Company.

ISRM (1981) The Complete ISRM Suggested Methods for Rock Characterization, Testing and Monitoring, Ankara, ISRM Turkish National Group.

Kementerian Energi dan Sumber Daya Mineral (2000) Keputusan Menteri Energi dan Sumber Daya Mineral Nomor 1452 K/10/MEM/2000 tentang Pedoman Teknis Pemetaan Zona Kerentanan Gerakan Tanah, Jakarta, Departemen Energi dan Sumber Daya Mineral.

Kementrian Pekerjaan Umum (2007) Pedoman Penataan Ruang Kawasan Rawan Bencana Longsor. Peraturan Menteri Pekerjaan Umum No. 22/PRT/M/2007, Jakarta, Departemen Pekerjaan Umum, Direktorat Jenderal Penataan Ruang.

Marinos, V., Marinos, P., Hoek, E. (2004) The geological strength index : applications and limitations, Athens, School of Civil Engineering, National Technical University of Athens.

Novianto, M.W.A., Djaja, Wahyudin (1997) Peta Geologi Teknik Lembar Yogyakarta, Skala 1 : 100.000, Bandung, Direktorat Geologi Tata Lingkungan.

Pusat Vulkanologi dan Mitigasi Bencana Geologi (2015) Peta Zona Kerentanan Gerakan Tanah Kota dan Kabupaten Magelang, Provinsi Jawa Tengah, Jakarta, Kementerian Energi dan Sumber Daya Mineral.

Rahardjo, W., Sukandarrumidi, Rosidi, H.M.D. (1995) Peta Geologi Lembar Yogyakarta, Skala 1 : 100.000, Bandung, Pusat Penelitian dan Pengembangan Geologi.

Saaty, T.L. (1990) How to make a decision: The Analityc Hierarchy Proces, European Journal of Op- 


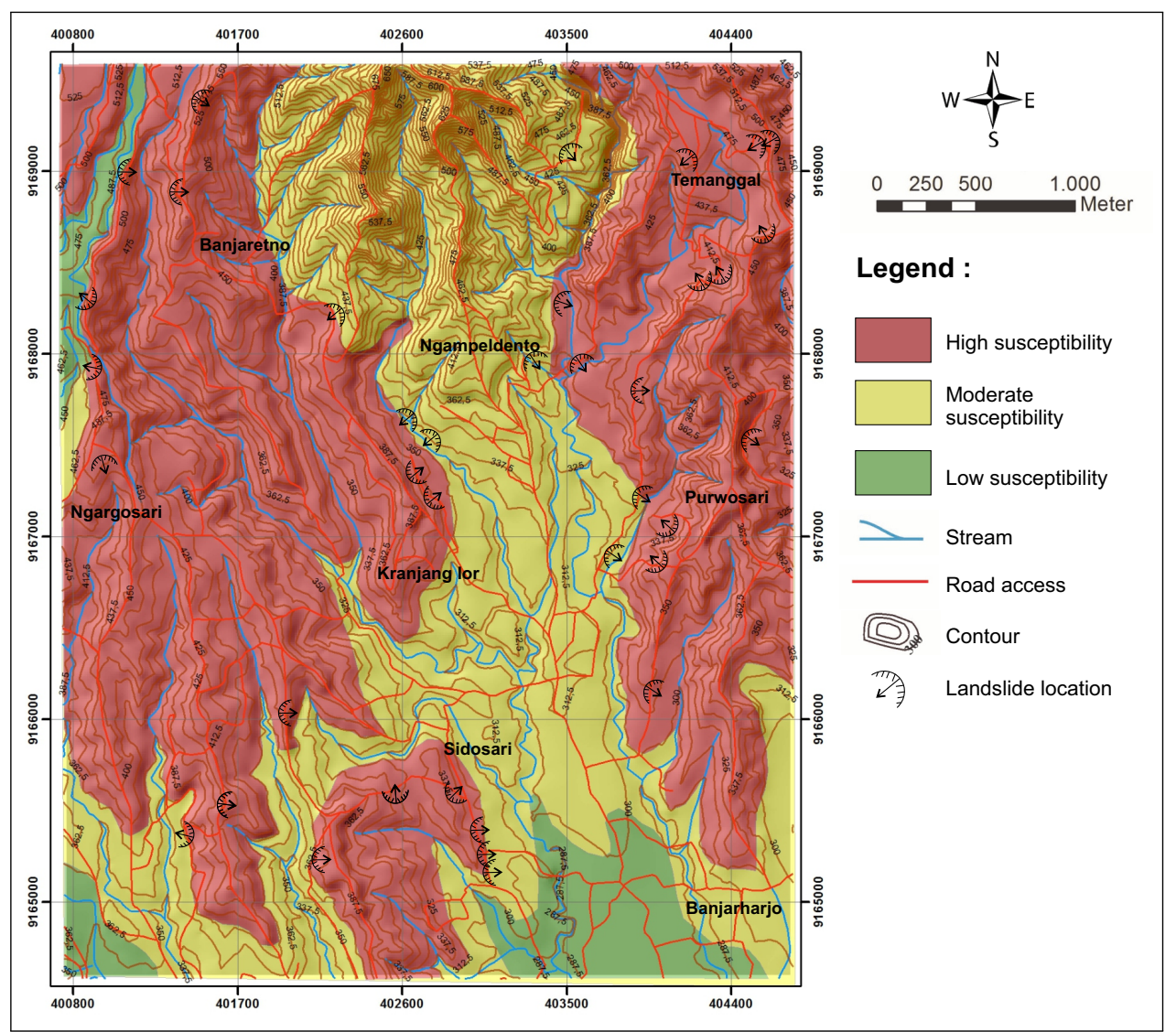

Figure 8: Map of landslide susceptibility.

erational Research 48, Pittsburgh, University of Pittsburgh.

Schmid, R. (1981) Descriptive nomenclature and classification of pyroclastic deposits and fragments: Recommendations of the IUGS Subcommision on the Systematics of Igneous Rocks, Zürich, Springer-Verlag.

Streckeisen, A., (1989) A Classification of Igneous
Rocks and Glossary of Terms: Recommendations of the International Union of Geological Sciences Subcommission on the Systematics of Igneous Rocks, Cambridge, Cambridge University Press.

Van Zuidam, R. A. (1985) Aerial PhotoInterpretation Terrain Analysis and Geomorphology Mapping, Smith Publisher The Hague, ITC. 